\title{
Natural Resource Rent and Financial Development Nexuses in Bangladesh: The Role of Institutional Quality
}

http://doi.org/10.21272/fmir.4(2).108-114.2020

\author{
Muhammad Atif Khan
}

School of Finance, Zhongnan University of Economics and Law, Wuhan, P.R. China

Kishwar Ali

School of Finance, Zhongnan University of Economics and Law, Wuhan, P.R. China

\begin{abstract}
This paper examines the relationship between the development of the financial sector of the economy and natural rents. The financial sector of the economy is currently an important driver of economic growth. The study was conducted through the prism of addressing two key issues: determining the nature of the impact of natural rents on the financial development of Bangladesh; study of the role of the quality of institutional mechanisms in the relationship between natural rent and financial development of Bangladesh. The study period includes 35 years, from 1984 to 2019 . The calculations were performed using an autoregressive model with a distributed lag, based on the order of integration and stationary properties of the variables of this study. The article presents the results of an empirical analysis, which showed a significant negative impact of the lease of natural resources on the financial development of Bangladesh. It is empirically confirmed that the quality of institutional mechanisms for the functioning of economic entities has a positive effect on the relationship between natural rents and the financial development of Bangladesh. The results of the study empirically confirm the hypothesis of insufficient natural resources in Bangladesh. The article emphasizes that the positive moderating role of the quality of the institutional base indicates that due to the strengthening of the institutional base, insufficient resources can become a benefit for the financial sector. The results of the study can be useful for representatives of the Government of Bangladesh from the standpoint of improving the quality of institutional infrastructure in order to ensure financial development, in which there will be positive effects from the implementation of natural resource lease processes. In the future, a study is planned to expand potential sources for the proper use of natural resource leases in Bangladesh.
\end{abstract}

Keywords: natural resource rent, financial development, institutional quality, Pakistan

JEL Classification: G1, G18, P28, P48.

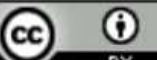

Cite as: Khan, M.A., Kishwar, A. (2020). Natural Resource Rent and Financial Development Nexuses in Bangladesh: The Role of Institutional Quality. Financial Markets, Institutions and Risks, 4 (2), 108114. http://doi.org/10.21272/fmir.4(2).108-114.2020.

(C) The Author, 2020. This article is published with open access at Sumy State University.

\section{Introduction}

Financial sector development is generally recognized as an important driver of economic growth and development of a country (Demetriades \& Andrianova, 2004; Levine, 2003; Pradhan, Bahmani, \& Kiran, 2014). Considering the importance of the financial sector, literature extensively focused on the sources/determinants of financial sector development. Recently, researchers have focused their attention on the impact of natural resource rent of financial sector development e.g. (Dwumfour \& Ntow-Gyamfi, 2018; Guan, Kirikkaleli, Bibi, \& Zhang, 2020; Mlachila \& Ouedraogo, 2019; Yuxiang \& Chen, 2011; Zaidi et al., 2019) but they reported conflicting findings. In economic literature, generally, natural resource dependence is considered as a hurdle to economic growth, and this phenomenon is labelled as "natural resource curse hypothesis" (NRCH) (Badeeb, Lean, \& Clark, 2017; van der Ploeg, 2011).

In resource-finance literature this hypothesis also got extensive support e.g. (Dwumfour \& Ntow-Gyamfi, 2018; Guan et al., 2020; Mlachila \& Ouedraogo, 2019; Yuxiang \& Chen, 2011) documented a negative impact 
Financial Markets, Institutions and Risks, Volume 4, Issue 2, 2020 ISSN (online) - 2521-1242 ISSN (print) - 2521-1250

of natural resources rent on various indicators of financial sector development. However, to the best of our knowledge, no scholarly evidence is available on the impact of natural resource rent on financial sector development in Bangladesh which is an important emerging and resource-rich economy. Furthermore, a strand of literature evidenced a decisive role of political institutions in determining the effect of natural resource rent on financial sector development. Natural resources are blessing or curse depends on the quality of political institutions (Badeeb et al., 2017).

On this backdrop, this study contributes to the literature by investigating the impact of natural resource rent on the financial sector of Bangladesh and the moderating role of institutions in the resource-finance relationship.

Specifically, this study addresses the following research questions:

Q.1 What is the impact of natural resource rent on financial development in Bangladesh?

Q.2 Do institutional quality moderates the relationship between natural resource rent and financial development in Bangladesh?

Our findings based on ARDL bound test to cointegration of (Pesaran, Shin, \& Smith, 2001) reveals a significant negative impact of natural resource rent on the financial development of Bangladesh and supports the natural resources resource curse hypothesis in the financial sector of Bangladesh. Furthermore, we documented a significantly positive moderating role of institutions in the resource-finance relationship in the context of Bangladesh.

The remaining study is structured as follows. Sector 2 summarizes the existing literature on the topic and hypothesis development, section 3 contains research design and strategy, section 4 contains empirical results and discussion and finally, section 5 provides conclusion and policy implications.

\section{$1 \quad$ Literature review}

There is a wide range of literature that studied the relationship between natural resource rent and financial sector development in a different contextual setting. Yuxiang and Chen (2011). Invesitagted the nexus between natural resource rent and various indicators of the financial sector and reported a negative impact of natural resource rent on financial development in the context of China. They contend that natural resource rent hinders financial development by negatively influencing trade, human capital, and enhancing corruption and rentseeking. In the same vein, Guan et al. (2020) also explored the relationship between natural resource rent and financial development. Their findings also support the resource curse hypothesis by showing a negative association between resource rent and financial development.

Mlachila and Ouedraogo (2019) evidenced the natural resource curse in a sample of resource dependence economies that operate through the channel of commodity price volatility. Kurronen (2015) reported a negative impact of the natural resource curse in the banking sector of sample counties. The literature identified various economic mechanism through which resource curse potentially operate and undermines various indicator of financial and economic development. For example 'Dutch disease'(Matsen \& Torvik, 2005; van Wijnbergen, 1984), corruption and rent-seeking (Baland \& Francois, 2000; Bhattacharyya, 2013; Petermann, Guzmán, \& Tilton, 2007), neglecting education or crowding out human capital (Gylfason, 2001) and deteriorating institutional quality (Eldomiaty, Al Qassemi, Mabrouk, \& Abdelghany) (Collier \& Hoeffler, 2005; Isham, Woolcock, Pritchett, \& Busby, 2005; Sala-i-Martin \& Subramanian, 2012) are the potential source through which resource course undermines economic and financial development of a country.

In contrast to this traditional version of natural resource rent and financial sector development nexuses, contrasting evidence also exist in literature. E.g. (Shahbaz, Naeem, Ahad, \& Tahir, 2018; Zaidi et al., 2019) show natural resource as a blessing and documented a significant positive relationship between natural resource rent and financial development. RecentlySun, Ak, Serener, and Xiong (2020) examined the impact of natural resource rent of financial sector development in E-7. They documented a significant negative association between natural resource rent and financial development in sample countries.

A strand of literature posits that resource rent and financial development relationship depends on the strength of the institutional framework in an economy. The high-quality institutional framework could turn the curse into a blessing by checking the potential channels through with resource rent undermines financial development i. corruption, rent-seeking, and weak contract enforcement. Natural resource rent deteriorates contract enforcement and hampers financial sector development only is that country with poor political institutions but not in counties where sound political institutions exist (Bhattacharya 2014). Similary Khan, 
Khan, Abdulahi, Liaqat, and Shah (2019)also finds that institutional quality positively moderates the nexuses between natural resource rent and financial development in the united states. They argue that high-quality institutions act as deterrence against corruption and rent-seeking and turns the curse into a blessing.

Bulte, Damania, and Deacon (2005) documented that when institutional quality plugged into mineral resource and financial development modeling the curse turns into a blessing. Furthermore, in line with existing literature, we used economic growth, human capital, capital, trade openness as controls for financial development in our mode to get robust results.

In sum, the majority of existing literature holds that natural resource rent hampers financial sector development by deteriorating contract enforcement, enhancing corruption, and rent-seeking in resource-dependent economies. However, institutional quality can check these channels through which natural resource rent hamper financial development and can turn the curse into a blessing.

Base on the given literature, we posit the following hypothesis for empirical testing:

H1: Natural resource rent hampers financial development in Bangladesh?

$\mathrm{H} 2$ : Institutional quality plays a significant positive moderating role in resource rent and financial development nexuses.

\section{$2 \quad$ Research Design and Methods}

\subsection{Data and Variables}

Based on the maximum availability of data we have used 35 years of annual time series data from 1984 to 2019 for our analysis. Consistent with literature e.g. (Shahbaz et al., 2018), We have measured financial development with " domestic credit to the private sector as a percentage of GDP", which is our dependent variable, and data is sourced from world Banks world development indicators 2019 (WB-WDI). We proxy natural resource rent which is our independent variable with the percentage of natural resource rent to GDP which we retrieved from WB-WDI and institutional quality is measured with quality of government index sources from the quality of government official website. Moreover, we have used economic growth, human capital, trade openness, and capital as control variables in our model for robust estimates. Real GDP per capita is employed as a proxy for economic growth, Human capital is measured with a percentage of the population with primary school enrollment, trade openness with a ratio of imports and exports to GDP and capital is measured with gross fixed capital formation. The data for all control variables are sourced from World Bank, World development indicators 2019.

\subsection{Econometric model and Methods}

This study empirically investigates the long-run association between natural resource rent and financial development along with the moderating role of institutional quality in this paradigm in an emerging and resource-rich economy of Bangladesh. To this end, resing on the exiting theoretical and empirical literature, our baseline econometric model takes the following form:

$$
\begin{gathered}
F D_{t}=\beta_{0}+\beta_{1} \ln N R R_{t}+\beta_{2} \ln I Q_{t}+\beta_{3} E C G+\beta_{4} \ln H C_{t}+\beta_{5} K_{t}+\beta_{6} T O_{t}+\beta_{7} I Q_{t} * N R R_{t} \\
+\mu_{i}
\end{gathered}
$$

Where $\beta_{0}$ depicts intercept, $\beta_{1}-\beta_{7}$ are the sequential coefficient of natural resource rent, institutional quality, economic growth, human capital, capital, trade openness, the interactive term of institutional quality and natural resource rent and $\mu_{i}$ shows an error term which is normally distributed.

Based on the order of integration/stationarity properties of our study variables, to address the research question empirically we used autoregressive distributed lag (ARDL) bounds-testing approach to cointegration of (Pesaran et al., 2001). Our variables are integrated of either order zero or order one. For such an order of integration, our proposed method is most suitable for analysis of the long-run and the short-run association between variables and is widely used in literature.

Based on (Pesaran et al., 2001) the ARDL bounds testing approach to cointegration has been specified by authors as follows in equations 2 . 


$$
\begin{aligned}
\ln F D_{t}=\gamma_{0}+\gamma_{1} \ln F D_{t-1}+\gamma_{2} \ln N R R_{t-1}+\gamma_{3} \ln I Q_{t-1}+\gamma_{4} \ln E C G_{t-1}+\gamma_{5} \ln H C_{t-1}+\gamma_{6} \ln K_{t-1}+\gamma_{7} \ln T O_{t-1} \\
+\gamma_{8} \ln I Q_{t-1} * \ln N R R_{t-1}+\sum_{t-1}^{r} \varphi_{9} \Delta \ln N R R_{t-1}+\sum_{t-0}^{u} \varphi_{10} \Delta \ln I Q_{t-1}+\sum_{t-0}^{u} \varphi_{11} \Delta \ln E C G_{t-1} \\
+\sum_{t-0}^{s} \varphi_{12} \Delta \ln H C_{t-1}+\sum_{t-0}^{t} \varphi_{K} \Delta \ln K_{t-1}+\sum_{t-0}^{u} \varphi_{13} \Delta \ln T O_{T-1}+\sum_{t-0}^{u} \varphi_{14} \Delta \ln I Q_{t-1} * \ln N R R_{t-1} \\
+\varphi_{15} D 1+\mu_{i}---{ }_{\text {Equation }}
\end{aligned}
$$

Here, $\Delta$ is the first difference operator, $t$ in subscript represent time, $a$ is intercept or constant parameter $p$ - $u$ is the optimal number of lags( determined by using AIC, SC and HQ criteria under VAR lag order selection criteria, not reported here for the sake of brevity) $\gamma$ and $\varphi$ are the short run and long run co-efficient respectively. $D$ indicates a dummy variable which captures the structural breaks in series determined by the Kim and Perron (2009), unit root test and $\mu_{i}$ indicates residuals.

\section{Results and Discussion}

Table 1 contains descriptive statistics i.e the mean, standard deviation, minimum and maximum values of the study variable. Descriptive statistics show the mean value of financial development economic growth and trade openness as compared to the other variables is higher and a higher standard deviation can be seen in the case of natural resource rent, financial development, and trade openness.

Table 1. Descriptive Statistics

\begin{tabular}{|l|c|c|c|c|c|}
\hline \multicolumn{1}{|c|}{ Variable } & Obs & Mean & Std. Dev. & Min & Max \\
\hline FD & 35 & 4.21 & 0.214 & 1.733 & 4.214 \\
\hline NRR & 35 & 2.061 & 0.417 & 2.147 & 3.748 \\
\hline IQ & 35 & 0.144 & 0.145 & 0.435 & 1.044 \\
\hline ECG & 35 & 3.062 & 0.215 & 2.571 & 3.442 \\
\hline HC & 35 & 2.717 & 0.211 & 6.321 & 7.109 \\
\hline K & 35 & 2.52 & 0.122 & 2.985 & 3.602 \\
\hline TO & 35 & 3.215 & 0.217 & 2.527 & 2.257 \\
\hline
\end{tabular}

Source: compiled by the author.

The first step before deciding econometric methods is to check the order of integration of study variables. Therefore, we have to use Dickey and Fuller (1979, 1981), and Phillip-Peron (PP) of Phillips and Perron (1988), tests to check the order of integration or stationarity properties of our study variables and results are reported in table 2 .

The results of the unit root tests suggest that all the variables of the study are either integrated of order zero or one and none of the variables is integrated of order higher than one. Hence, Based on the order of integration/stationarity properties of our study variables, to address the research question empirically we used autoregressive distributed lag (ARDL) bounds-testing approach to cointegration of (Pesaran et al., 2001).

Table 2. Stationarity Testing

\begin{tabular}{|l|c|c|c|c|c|c|}
\hline & \multicolumn{3}{|c|}{ Level } & \multicolumn{3}{c|}{ First difference } \\
\hline \multicolumn{1}{|c|}{ Variable } & ADF & PP & KP & ADF & PP & KP \\
\hline FD & -1.61 & -6.14 & -3.12 & $-2.15^{* * *}$ & $-8.20^{* * *}$ & $-6.52^{* * *}$ \\
\hline NRR & -3.74 & -1.95 & -2.48 & $-5.43^{* * *}$ & $-3.41^{* * *}$ & $-5.42^{* * *}$ \\
\hline IQ & -3.29 & $-1.23^{*}$ & -1.412 & -3 * $^{* *}$ & $-4.69^{* * *}$ & $-6.478^{* * *}$ \\
\hline NRR*IQ & $-2.44^{*}$ & -1.66 & -3.24 & $-4.15^{* * *}$ & $-4.14^{* * *}$ & $-3.45^{* * *}$ \\
\hline EG & -1.15 & -3.05 & -3.61 & $-3.21^{* * *}$ & $-4.74^{* * *}$ & $-3.52^{* * *}$ \\
\hline HC & -2.50 & -2.49 & -3.47 & $-4.84^{* * *}$ & $-3.35^{* * *}$ & $-3.12^{* * *}$ \\
\hline K & -2.34 & -1.14 & -2.03 & $-5.39^{* * *}$ & $-5.42^{* * *}$ & $-5.69^{* * *}$ \\
\hline TO & $-2.32^{*}$ & -2.45 & -2.75 & $-4.01^{* * *}$ & $-5.43^{* * *}$ & $-5.53^{* * *}$ \\
\hline
\end{tabular}

Source: compiled by the author.

After examining the order of integration of the variables, we have applied ARDL bound test to cointegration, and results are given in Table 3. Results show that ARDL F-statistics is higher than upper bond critical values suggested by (Pesaran et al., 2001), at all levels of significance. This proves the existence of the long-run cointegration relationship between natural resource rent, institutional quality, and financial sector development during the study period in Bangladesh. Moreover, the diagnostics tests reported in the last four columns of 
Table 3 confirms the robustness and reliability of findings obtained from the ARDL bounds test. of (Pesaran et al., 2001) for policy implications.

Table 3. ARDL Bounds Test to Cointegration

\begin{tabular}{|l|l|l|l|l|l|l|l|l|}
\hline & Method & & \multicolumn{4}{|l|}{ Stability and diagnostic statistics } \\
\hline & ARDL bound test & Lag order & F-Stat. & Breakpoint & JB & LM & BPG & RR \\
\hline $\begin{array}{l}\text { FDt } \\
\text { ECGt,ERt,TOt, Kt) }\end{array}$ & $(2,1,2,0,2,2,1,0)$ & $4.247^{* * *}$. & 2007 & 0.784 & 0.472 & 0.254 & 0.147 \\
\hline
\end{tabular}

Source: compiled by the author.

Note: $(* * *)(* *)$ and $(*)$ depicts level of significance at $1 \%, 5 \%$ and $10 \%$ respectively. JB is the p-values of Jarque-Bera; LM depicts p-values of LM- Breusch-Godfrey Serial Correlation LM Test; PBG is p-values of Heteroskedasticity Test: BPG and RR are the pvalues of Breusch-Pagan-Godfrey test and RR-Ramsey RESET test of model stability, respectively.

After confirmation of the long-run cointegration relationship between our variables of interest, we proceeded with the estimation of short-run and long-run coefficients. The results of the short and long-run analyses are presented in Table 5. Results shows that natural resource rent has a negative impact on financial development in Bangladesh during the study period. Furthermore, institutional quality positively drives financial development and significantly positively moderates the nexuses between natural resource rent and financial development. Hence our results confirm the presence of a resource curse in the financial sector of Bangladesh and support the Resource Curse Hypothesis. Furthermore, our findings confirm the decisive role of institutional quality in determining the impact of natural resource rent on financial development. The significant positive coefficient of moderating term suggests that institutional quality turns the curse into blessings and it is the tool to evade the resource curse. Our results conform with the existing literature on the subject e.g (Bhattacharyya \& Hodler, 2010, 2014; Khan et al., 2019; Shahbaz et al., 2018; Yuxiang \& Chen, 2011) reported similar findings in various contexts. Furthermore, the coefficient of error term i.e (ECMt-1), is significant negative which provide further evidence that there exist integration between FD of Bangladesh and its various determinants included in the model and any deviation from the equilibrium relationship in the short run is rectified with an average speed of $54 \%$ annually.

Table 4. Short-run and long-run analysis

\begin{tabular}{|c|c|c|}
\hline \multicolumn{3}{|c|}{ Dependent variable: $F D$} \\
\hline Variables & Long-run & Short-run \\
\hline NRR & $-0.089 * * *$ & $-0.051 * * *$ \\
\hline & $(-5.24)$ & $(-5.34)$ \\
\hline IQ & $0.196 * * *$ & $0.020 * * *$ \\
\hline & $(9.73)$ & $(3.97)$ \\
\hline NRR*IQ & $0.069 * * *$ & $0.044 * * *$ \\
\hline & $(3.58)$ & $(7.03)$ \\
\hline EG & $0.058 * * *$ & $0.121 * * *$ \\
\hline & $(10.53)$ & $(5.76$ \\
\hline $\mathrm{HC}$ & $0.324 * * *$ & $0.200 * * *$ \\
\hline & $(10.32)$ & $(5.98)$ \\
\hline K & $0.329 * * *$ & $0.130 * * *$ \\
\hline & -10.29 & -8.94 \\
\hline TO & $0.314 * * *$ & $0.025 * * *$ \\
\hline & $(9.74)$ & $(3.73)$ \\
\hline ECMt-1 & & $-0.540 * * *$ \\
\hline & & $(-5.98)$ \\
\hline Constant & $-9.026^{* * *}$ & $-5.131 * * *$ \\
\hline & $(-8.63)$ & $(-2.60)$ \\
\hline R-Squared & 0.610 & \\
\hline F-statistic & $54.23 * *$ & \\
\hline Diagnostic and Stability tests & & \\
\hline JB & $2.14 * *$ & \\
\hline LM & $1.58^{* * *}$ & \\
\hline BPG & $2.17^{* * *}$ & \\
\hline $\mathrm{RR}$ & $1.14 * *$ & \\
\hline
\end{tabular}

Note: $\left.{ }^{* * *}\right)\left({ }^{* *}\right)$ and $\left({ }^{*}\right)$ depicts level of significance at $1 \%, 5 \%$ and $10 \%$ respectively. JB is the p-values of Jarque-Bera; LM depicts p-values of LM- Breusch-Godfrey Serial Correlation LM Test; PBG is p-values of Heteroskedasticity Test: BPG and RR are the p-values of Breusch-Pagan-Godfrey test and RR-Ramsey RESET test of model stability, respectively.

Source: compiled by the author. 


\section{Conclusion}

This study examines the relationship between natural resource rent and financial sector development by incorporating the vital role of institutional quality in this paradigm in an emerging and resource-rich economy of Bangladesh, from 1984 to 2019. To this end, we have employed the ARDL cointegration test for empirical analysis and answering the research questions. Our findings based on ARDL bound test reveals a significant negative association between natural resource rent and financial development in Bangladesh and strongly support the natural resource curse hypothesis (NRCH). Furthermore, our study divulges that institutional quality significantly positively moderates the relationship between natural resource rent and financial development. Based on our findings, we recommend policymakers in Bangladesh to enhance the quality of their institutional framework to get financial development promoting the benefits of natural resource rent and turn resource curse into a blessing.

Future studies can extend this strand of literature by investigating other potential sources for the proper utilization of natural resource rent in Bangladesh.

\section{References}

1. Badeeb, R. A., Lean, H. H., \& Clark, J. (2017). The evolution of the natural resource curse thesis: A critical literature survey. Resources Policy, 51, 123-134. doi: https://doi.org/10.1016/j.resourpol.2016.10.015

2. Baland, J.-M., \& Francois, P. (2000). Rent-seeking and resource booms. Journal of Development Economics, 61(2), 527-542. doi: https://doi.org/10.1016/S0304-3878(00)00067-5

3. Bhattacharyya, S. (2013). Political origins of financial structure. Journal of Comparative Economics, 41(4), 979-994. doi: https://doi.org/10.1016/j.jce.2013.05.009

4. Bhattacharyya, S., \& Hodler, R. (2010). Natural resources, democracy and corruption. European Economic Review, 54(4), 608-621. doi: https://doi.org/10.1016/j.euroecorev.2009.10.004

5. Bhattacharyya, S., \& Hodler, R. (2014). Do Natural Resource Revenues Hinder Financial Development? The Role of Political Institutions. World Development, 57, 101-113. doi: https://doi.org/10.1016/j.worlddev.2013.12.003

6. Bulte, E. H., Damania, R., \& Deacon, R. T. (2005). Resource intensity, institutions, and development. World Development, 33(7), 1029-1044. doi: https://doi.org/10.1016/j.worlddev.2005.04.004

7. Collier, P., \& Hoeffler, A. (2005). Resource Rents, Governance, and Conflict. Journal of Conflict Resolution, 49(4), 625-633. doi:10.1177/0022002705277551

8. Demetriades, P., \& Andrianova, S. (2004). Finance and Growth: What We Know and What We Need To Know. In: Goodhart, C.A.E. (Ed.), Financial Development and Economic Growth. British Association for the Advancement of Science. Palgrave Macmillan, London, 38-65. Retrieved from: https://econpapers.repec.org/paper/lecleecon/03_2f15.htm

9. Dickey, D. A., \& Fuller, W. A. (1979). Distribution of the Estimators for Autoregressive Time Series with a Unit Root. Journal of the American Statistical Association, 74(366a), 427-431. doi:10.1080/01621459.1979.10482531

10. Dickey, D. A., \& Fuller, W. A. (1981). Likelihood Ratio Statistics for Autoregressive Time Series with a Unit Root. Econometrica, 49(4), 1057-1072. doi:10.2307/1912517

11. Dwumfour, R. A., \& Ntow-Gyamfi, M. (2018). Natural resources, financial development and institutional quality in Africa: Is there a resource curse? Resources Policy, 59, 411-426. doi: https://doi.org/10.1016/j.resourpol.2018.08.012

12. Eldomiaty, T. I., Al Qassemi, T. B. F., Mabrouk, A. F., \& Abdelghany, L. S. (2016). Institutional quality, economic freedom and stock market volatility in the MENA region. Macroeconomics and Finance in Emerging Market Economies, 9(3), 262-283. doi:10.1080/17520843.2015.1093011

13. Guan, J., Kirikkaleli, D., Bibi, A., \& Zhang, W. (2020). Natural resources rents nexus with financial development in the presence of globalization: Is the "resource curse" exist or myth? Resources Policy, 66, 101641. doi: https://doi.org/10.1016/j.resourpol.2020.101641

14. Gylfason, T. (2001). Natural resources, education, and economic development. European Economic 
Review, 45(4), 847-859. doi: https://doi.org/10.1016/j.resourpol.2020.101641

15. Isham, J., Woolcock, M., Pritchett, L., \& Busby, G. (2005). The Varieties of Resource Experience: Natural Resource Export Structures and the Political Economy of Economic Growth. The World Bank Economic Review, 19(2), 141-174. doi:10.1093/wber/lhi010

16. Khan, M. A., Khan, M. A., Abdulahi, M. E., Liaqat, I., \& Shah, S. S. H. (2019). Institutional quality and financial development: The United States perspective. Journal of Multinational Financial Management, 49, 67-80.

17. Kim, D., \& Perron, P. (2009). Unit root tests allowing for a break in the trend function at an unknown time under both the null and alternative hypotheses. Journal of Econometrics, 148(1), 1-13. doi: https://doi.org/10.1016/j.jeconom.2008.08.019

18. Matsen, E., \& Torvik, R. (2005). Optimal Dutch disease. Journal of Development Economics, 78(2), 494515. doi: https://doi.org/10.1016/j.jdeveco.2004.09.003

19. Mlachila, M., \& Ouedraogo, R. (2019). Financial development curse in resource-rich countries: The role of commodity price shocks. The Quarterly Review of Economics and Finance. doi: https://doi.org/10.1016/j.qref.2019.04.011

20. Petermann, A., Guzmán, J. I., \& Tilton, J. E. (2007). Mining and corruption. Resources Policy, 32(3), 91103. doi: https://doi.org/10.1016/j.resourpol.2007.08.003

21. Pradhan, R. P., Bahmani, S., \& Kiran, M. U. (2014). The dynamics of insurance sector development, banking sector development and economic growth: Evidence from G-20 countries. Global Economics and Management Review, 19(1), 16-25. doi: https://doi.org/10.1016/j.gemrev.2015.05.001

22. Sala-i-Martin, X., \& Subramanian, A. (2012). Addressing the Natural Resource Curse: An Illustration from Nigeria†. Journal of African Economies, 22(4), 570-615. doi:10.1093/jae/ejs033

23. Shahbaz, M., Naeem, M., Ahad, M., \& Tahir, I. (2018). Is natural resource abundance a stimulus for financial development in the USA? Resources Policy, 55, 223-232. doi: https://doi.org/10.1016/j.resourpol.2017.12.006

24. Sun, Y., Ak, A., Serener, B., \& Xiong, D. (2020). Natural resource abundance and financial development: A case study of emerging seven (E-7) economies. Resources Policy, 67, 101660. doi: https://doi.org/10.1016/j.resourpol.2020.101660

25. van der Ploeg, F. (2011). Natural Resources: Curse or Blessing? Journal of Economic Literature, 49(2), 366-420. doi:10.1257/jel.49.2.366

26. van Wijnbergen, S. (1984). The 'Dutch Disease': A Disease After All? The Economic Journal, 94(373), 41-55. doi:10.2307/2232214

27. Yuxiang, K., \& Chen, Z. (2011). Resource abundance and financial development: Evidence from China. Resources Policy, 36(1), 72-79. doi: https://doi.org/10.1016/j.resourpol.2010.05.002

28. Zaidi, S. A. H., Wei, Z., Gedikli, A., Zafar, M. W., Hou, F., \& Iftikhar, Y. (2019). The impact of globalization, natural resources abundance, and human capital on financial development: Evidence from thirty-one OECD countries. Resources Policy, 64, 101476. doi: https://doi.org/10.1016/j.resourpol.2019.101476 